\title{
Comparison of Single Exponential Smoothing, Naive Model, and SARIMA Methods for Forecasting Rainfall in Medan
}

\section{Perbandingan Metode Single Exponential Smoothing, Naive Model, dan SARIMA untuk Peramalan Curah Hujan Di Kota Medan}

\author{
Arnita $^{1}$, Dina Novriyana ${ }^{1}$, Faridawaty Marpaung ${ }^{1}$, Anisa $^{2}$
}

\begin{abstract}
This study aims to compare the best method on the forecasting system of rainfall in Medan using Single Exponential Smoothing (SES), Naive Model, and Seasonal Autoregressive Integrated Moving Average (SARIMA). The data used in this study is rainfall data for 10 years $(2009$ - 2019) source http://dataonline.bmkg.go.id/data_iklim. From the simulation by comparing existing method, the best model is SES with $\alpha=0.9$ and value of MAPE (Mean Absolut Percentage Error) sebesar 2,47\%. And then SARIMA $(1,01,1)(4,0,3)^{12}$ whit value of MAPE is $2,93 \%$. Both of this model is high accurate model because value of MAPE resulted $<10 \%$.
\end{abstract}

Keywords: Exponential Smoothing, Forecasting, Naive Model, SARIMA

\begin{abstract}
Abstrak
Penelitian ini bertujuan untuk membandingkan metode yang terbaik pada sistem peramalan curah hujan di kota Medan menggunakan Single Exponential Smoothing (SES), Naive Model, dan Seasonal Autoregressive Integrated Moving Average (SARIMA). Data yang digunakan dalam penelitian ini adalah data curah hujan selama 10 tahun (2009-2019) sumber data http://dataonline.bmkg.go.id/data_iklim. Dari simulasi yang dilakukan dengan membandingan metode yang ada, maka diperoleh model terbaik adalah model SES dengan $\alpha=0.9$ dan nilai MAPE (Mean Absolut Percentage Error) sebesar 2,47\%. Kemudian model SARIMA $(1,01,1)(4,0,3)^{12}$ dengan nilai MAPE (Mean Absolut Percentage Error) sebesar 2,93\%. Kedua model ini termasuk dalam high accurate model karena nilai MAPE yang dihasilkan $<10 \%$.
\end{abstract}

Kata kunci: Exponential Smoothing, Naive Model, Peramalan, SARIMA

\section{Pendahuluan}

\footnotetext{
${ }^{1}$ Jurusan Maatematika Universitas Negeri Medan

${ }^{2}$ Jurusan Matematika Unversitas Hasanuddin
} 


\section{Arnita, Dina Novriyana, Faridawaty Marpaung, Anisa}

Peramalan merupakan suatu kegiatan untuk memprediksi kejadian di masa yang akan datang dengan menggunakan dan mempertimbangkan data dari masa lampau [1]. Peramalan yang menggunakan analisis pola hubungan antara variable yang diamati dan variable waktu disebut dengan peramalan time series. Pola musiman merupakan fluktuasi dari data yang terjadi secara periodik dalam kurun waktu tertentu seperti harian, mingguan atau bulanan. Jika data mempunyai pola musiman, maka metode yang cocok untuk peramalan adalah Seasonal Autoregressive Integrated Moving Average (SARIMA) [2]. Metode SARIMA merupakan metode yang paling populer untuk peramalan musiman. Namun pemenuhan asumsi stasioner dan bebas dari white noise menjadi hal yang wajib dipenuhi sehingga peramalan memberikan hasil yang lebih akurat.

Beberapa teknik dapat digunakan untuk meningkatkan keakurasian model time series. Salah satu metode yang sering digunaka adalah dengan cara pemulusan data (smoothing). Terdapat beberapa metode smoothing yang umum digunakan dalam peramalan time series diantaranya adalah Naive Model, Simple Average, Moving Average, Single Exponential Smoothing, Double Moving Average, Double Exponential Smoothing, Winters, dll. Penggunaan metode pemulusan ini bergantung pada pola data aktual yang ada.

Metode Single Exponential Smoothing adalah metode yang menunjukan pembobotan menurun secara eksponensial terhadap nilai observasi waktu sebelumnya. Dimana nilai yang lebih baru diberikan bobot yang relatif lebih besar dibanding nilai observasi yang lebih lama. Berdasarkan hasil penelitian [3], hasil yang diperoleh dari peramalan menggunakan metode Single Exponential Smoothing lebih tepat dibanding metode Exponential Smoothing Adjusted for Trend (Holt's Method). Hal ini ditunjukkan oleh nilai persentase kesalahan (MAPE) dan nilai MAD (forcast error) pada metode Single Exponential Smoothing lebih kecil dibanding metode Exponential Smoothing Adjusted for Trend (Holt's Method). Montgomery D (1990) menerangkan bahwa exponential smoothing adalah metode yang banyak digunakan dalam analisis time series. Banyaknya penggunaan ini dapat dikaitkan dengan kesederhanaan, efisiensi komputasi, kemudahan menyesuaikan respon terhadap perubahan dalam proses perkiraan, dan akurasi yang wajar [4].

Naive model merupakan metode yang paling sederhana, menganggap bahwa peramalan periode berikutnya sama dengan nilai aktual periode sebelumnya [5]. Metode ini dianggap metode yang efektif dan efisien dalam memberikan titik awal dari metode lainnya.

Provinsi Sumatera Utara memiliki kondisi geografi dan topografi yang beragam dan termasuk wilayah yang dikenai pola hujan ekuatorial yang bersifat bimodal. Curah hujan yang bersifat bimodal dibagi menjadi empat periode musiman yaitu periode Januari-Maret, April-Juni, Juli-September dan Oktober-Desember [6]. Kota Medan sebagai ibu kota provinsi Sumatera Utara memiliki variabilitas curah hujan tinggi. Kota Medan memiliki curah hujan rata-rata 2000 - $2500 \mathrm{~mm}$ per tahun [7].

Besarnya curah hujan sangat mempengaruhi kesejahteraan kehidupan masyarakat kota Medan, seperti dalam bidang industri, pendidikan, kesehatan, pariwisata, dll. Informasi mengenai kondisi dan pola curah hujan sangat penting untuk membantu proses perencanaan 


\section{Arnita, Dina Novriyana, Faridawaty Marpaung, Anisa}

dan kegiatan sehari-hari. Besarnya curah hujan yang akan terjadi di masa mendatang tidak dapat ditentukan secara pasti, namun dapat diprediksi atau diperkirakan dengan menggunakan data historis besarnya curah hujan beberapa waktu yang lampau [7]. Oleh karena itu perlu dikembangkan metode peramalan yang akurat dalam memberikan informasi peramalan curah hujan. Dalam penelitian ini akan dilakukan perbandingan hasil peramalan curah hujan di kota medan menggunakan metode SARIMA, metode Single Exponential Smoothing dan metode Nä̈ve.

\section{Metodologi}

\subsection{Data Stasioner}

Suatu data dikatakan stasioner jika memiliki mean, variance, dan fungsi autokorelasi yang konstan terhadap waktu [8]. Dalam melakukan peramalan time series, kestasioneran dapat dilihat dari grafik. Apabila data stasioner maka grafiknya akan mempunyai kecenderungan konstan di sekitar nilai rata-ratanya dengan amplitudo yang relatif tetap atau tidak terlihat adanya trend naik atau turun.

Untuk memastikan kestasioneran secara statistik dilakukan uji akar unit Augmented Dicky Fuller (ADF) dengan hipotesis uji adalah :

H0 $: \rho=0$ terdapat akar unit, data tidak stasioner

Ha $: \rho \neq 0$ tidak terdapat akar unit, data stasioner

Kriteria keputusan $\mathrm{H}_{0}$ ditolak jika $\mathrm{t} \mathrm{ADF}>\mathrm{t}$ tabel, $\mathrm{p}$-value $<\alpha=0,05$

\subsection{Single Exponential Smoothing (SES)}

Penghalusan eksponensial adalah teknik peramalan rata-rata bergerak dengan pembobotan dimana data diberi bobot oleh sebuah fungsi eksponensial [4]. Metode Pemulusan Eksponensial Tunggal (SES) merupakan metode penghalusan data dengan memberikan bobot yang lebih besar terhadap data yang lebih baru. Pendekatan ini memberikan bobot yang menurun secara geometris pada pengamatan yang lebih lama. Dengan teknik ini data dihaluskan dengan menghapus komponen tak teratur dalam data [9].

$$
\begin{aligned}
& S_{t}=\alpha X_{t}+(1-\alpha) S_{t-1} \\
& F_{t}=S_{t} \\
& F_{t+1}=F_{t}+\alpha\left(X_{t}-F_{t}\right) \\
& F_{t+1}=F_{t}+\alpha\left(e_{t}\right)
\end{aligned}
$$

Inisialisasi data $S_{0}$ secara umum dapat menggunakan $S_{0}=X_{1}$.

Keterangan:

$S_{t}=$ data yang telah di smoothing pada waktu $\mathrm{t}$, dengan $\mathrm{t}=1,2, \ldots, \mathrm{T}$.

$X_{t}=$ data aktual pada waktu $\mathrm{t}$, dengan $\mathrm{t}=1,2, \ldots, \mathrm{T}$.

$F_{t}=$ data ramalan pada waktu $\mathrm{t}$, dengan $\mathrm{t}=1,2, \ldots, \mathrm{T}$.

$e_{t}=$ selisih nilai data aktual dengan nilai ramalan pada waktu $\mathrm{t}$, dengan $\mathrm{t}=1,2, \ldots, \mathrm{T}$

$\alpha=$ parameter pembobot (faktor pengali) dengan $0<\alpha<1$

\subsection{Naive Model}

Merupakan metode peramalan yang sangat sederhana, mengganggap bahwa peramalan periode berikutnya sama dengan nilai aktual periode sebelumnya. Dengan demikian, data 


\section{Arnita, Dina Novriyana, Faridawaty Marpaung, Anisa}

aktual periode waktu yang baru saja berlalu merupakan alat peramalan terbaik untuk meramalkan keadaan di masa yang akan datang. Metode Naive sering digunakan sebagai pembanding karena kemudahan dalam memperoleh hasil peramalan [4]. Formula yang digunakan pada metode Naive yaitu:

$$
X_{t+1}=X_{t}
$$

Dimana $X_{t}$ adalah data aktual pada periode t. Jadi, nilai peramalan untuk data selanjutnya sama dengan data aktual sebelumnya [11].

\subsection{Metode SARIMA}

Musiman berarti kecenderungan mengulangi pola tingkah gerak dalam periode musim. Data runtun waktu sering menunjukkan perilaku periodik yang berulang setiap kelipatan $S$ periode waktu, dengan $S>1$. Secara umum, bentuk model SARIMA(p,d,q)(P,D,S $)^{\mathrm{S}}$ adalah

$$
\Phi_{P}\left(B^{S}\right) \phi_{p}(B)(1-B)^{d}\left(1-B^{S}\right)^{D} x_{t}=\theta_{q}(B) \Theta_{Q}\left(B^{S}\right) \varepsilon_{t}
$$

Dimana

$(p, d, q)=$ orde $\operatorname{AR}(p)$, orde differencing $(d)$, orde $\operatorname{MA}(q)$ untuk data non musiman

$(\mathrm{P}, \mathrm{D}, \mathrm{S})=$ orde $\mathrm{AR}(P)$, orde differencing $(D)$, orde $\mathrm{MA}(Q)$ untuk data musiman

$\mathrm{S} \quad=$ Periode musiman

$\Phi_{P}(B)=$ komponen AR musiman dengan orde $(P)$

$\phi_{p}(B)=$ komponen AR non musiman dengan orde $(p)$

$\Theta_{Q}\left(B^{S}\right)=$ komponen MA musiman dengan orde $(Q)$

$\theta_{q}(B) \quad=$ komponen MA non musiman dengan orde $(q)$

$\left(1-B^{S}\right)^{D}=$ differencing musiman dengan orde $(D)$

$(1-B)^{d}=$ differencing non musiman dengan orde $(d)$

$x_{t} \quad=$ besarnya pengamatan kejadian pada waktu ke-t

\subsection{Alat Evaluasi Akurasi Model}

Metode yang baik adalah metode yang memiliki tingkat akurasi yang tiggi. Untuk mengukur akurasi, perlu dihitung tingkat kesalahan dalam suatu prediksi. Semakin kecil tingkat kesalahan yang dihasilkan maka semakin akurasi hasil prediksi tersebut. Ada beberapa alat ukur yang dapat digunakan untuk mengevaluasi hasil peramalan terhadap data observasi. Beberapa diantaranya adalah Mean Square Error (MSE), Root Mean Square Error (RMSE), Mean Absolute Error (MAE), dan Mean Absolute Percentage Error (MAPE) [4].

\subsubsection{Mean Square Error (MSE)}

Model yang baik dinilai dengan melihat nilai MSE terkecil.

$$
M S E=\frac{1}{n} \sum_{t=1}^{n}\left(X_{t}-\hat{X}_{t}\right)^{2}
$$

Dimana

$X_{t}=$ nilai observasi pada periode ke- $\mathrm{t}$

$\hat{X}_{t}=$ nilai peramalan pada periode ke-t

$\mathrm{n}$ = banyaknya data observasi 


\section{Arnita, Dina Novriyana, Faridawaty Marpaung, Anisa}

\subsubsection{Root Mean Square Error (RMSE)}

RMSE digunakan untuk mengukur kesalahan nilai dugaan model yang dinyatakan dalam bentuk rata-rata akar dari kesalahan kuadrat. Rumus untuk menentukan nilai RMSE dinyatakan dengan persamaan [13].

$$
R M S E=\frac{1}{n} \sum_{t=1}^{n} \sqrt{\left(X_{t}-\hat{X}_{t}\right)^{2}}
$$

RMSE digunakan untuk membandingkan beberapa model estimasi dari sebuah runtun waktu yang sama. Model RMSE yang lebih kecil cenderung akan memiliki variansi galat ramalan yang lebih kecil.

\subsubsection{Mean Absolute Error (MAE)}

MAE digunakan untuk mengukur kesalahan dengan model yang dinyatakan dalam bentuk rata-rata absolute kesalahan. Rumus untuk menentukan nilai MAE dinyatakan dengan persamaan [13].

$$
M A E=\frac{\sum\left|\hat{X}_{t}-X_{t}\right|}{n}
$$

\subsubsection{Mean Absolute Percentage Error (MAPE)}

MAPE digunakan untuk mengukur kesalahan nilai dugaan model yang dinyatakan dalam bentuk persentase rata-rata absolute kesalahan. MAPE memberikan petunjuk tentang besarnya kesalahan peramalan dibandingkan dengan nilai sebenarnya. MAPE dihitung dengan menggunakan persamaan:

Dimana

$$
\begin{aligned}
& P E_{t}=\frac{X_{t}-\hat{X}_{t}}{X_{t}} \times 100 \% \\
& M A P E=\sum_{t=1}^{n} \frac{\left|P E_{t}\right|}{n}
\end{aligned}
$$

$X_{t} \quad=$ nilai aktual pada periode ke- $\mathrm{t}$

$X_{t} \quad=$ nilai peramalan pada periode ke-t

$\mathrm{n} \quad=$ banyaknya data observasi

$\left|P E_{t}\right| \quad=$ nilai absolut $P E_{t}$

Interpretasi dari hasil perhitungan MAPE yaitu [14]:

$<10 \%=$ highly accurate forecasting

$10 \%-20 \%=$ good forecasting

$20 \%-50 \%=$ reasonable forecasting

$>50 \%=$ weak and inaccurate predictability

\section{Hasil dan Pembahasan}

\subsection{Uji kestasioneran data}

Stasioner merupakan suatu kondisi data time series yang jika rata-rata, varian dan covarian dari peubah-peubah tersebut seluruhnya tidak dipengaruhi oleh waktu. Identifikasi kestasioneran data terhadap rataan dapat dilihat dari pola fluktuatif yang 


\section{Arnita, Dina Novriyana, Faridawaty Marpaung, Anisa}

cenderung sama. Berikut ini adalah plot data curah hujan kota Medan per bulan mulai dari bulan Januari 2009 sampai Juni 2019.

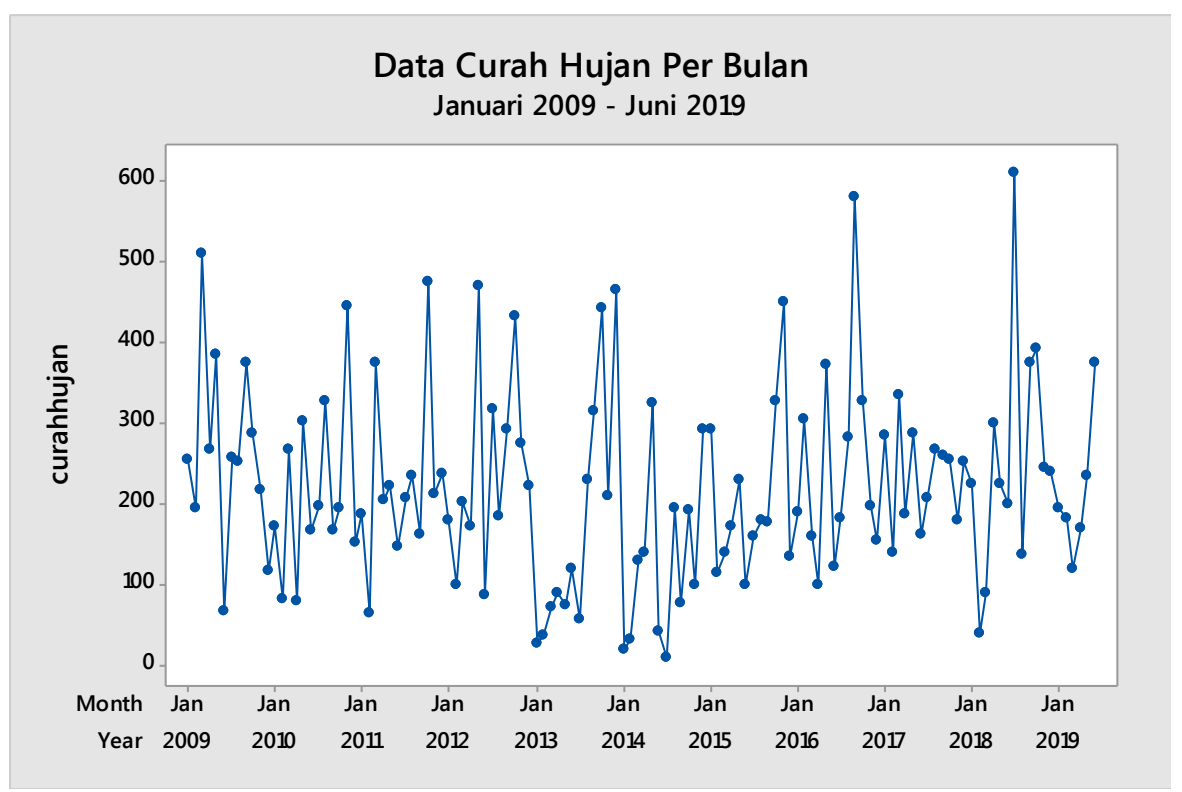

Gambar 3.1. Grafik time series data curah hujan per bulan

Pola data yang terlihat pada Gambar 3.1 menunjukkan bahwa data mempunyai kecenderungan konstan di sekitar nilai rata-ratanya dengan amplitudo yang relatif tetap atau tidak terlihat adanya trend naik atau turun. Artinya, data yang akan digunakan untuk peramalan curah hujan di Kota Medan sudah stasioner. Namun untuk memastikan apakah asumsi stasioner sudah terpenuhi maka dilakukan pengujian hipotesis menggunakan uji akar Augmented Dickey Fuller (ADF).

Tabel 3.1. Nilai ADF Uji Kestasioneran Data.

\begin{tabular}{cccc}
\hline & t-Statistic & Prob.* \\
\hline \multicolumn{2}{l}{ Augmented Dickey-Fuller test statistic } & -2.634 & \multirow{2}{*}{0.266} \\
\hline Test critical values: & $1 \%$ level & -4.041 & \\
& $5 \%$ level & -3.449 & \\
& $10 \%$ level & -3.150 & \\
& & & \\
\end{tabular}

Berdasarkan hasil uji ADF yang ditunjukkan pada Tabel 3.1 bahwa nilai statistik t $2.633>$ nilai kritis -3.449 pada taraf signifikan sebesar 5\%. Hal ini menunjukkan bahwa data sudah stasioner.

\subsection{Metode Single Exponential Smoothing (SES)}




\section{Arnita, Dina Novriyana, Faridawaty Marpaung, Anisa}

Setelah melakukan uji kestasioneran data, maka dilakukan teknik pemulusan menggunakan metode Single Exponential Smoothing (SES). Pemulusan ini bertujuan untuk mendapatkan hasil peramalan yang lebih akurat. Dalam pemulusan yang dilakukan dengan metode SES digunakan parameter $\alpha$ sebagai pembobot untuk menghasilkan error yang lebih kecil. Untuk mendapatkan nilai $\alpha$ yang tepat pada umumnya dilakukan uji coba sehingga diperoleh nilai kesalahan (error) paling kecil [12]. Umumnya nilai pembobot $\alpha$ berada pada nilai $0-1$, namun dalam penelitian ini dicobakan nilai $\alpha=0.1$ dan $\alpha=0.9$ untuk mengetahui nilai pembobot yang memberikan error paling kecil. Begitu juga dengan penentuan nilai awal $S_{0}$, beberapa nilai awal $S_{0}$ yang dapat digunakan adalah data pertama atau nilai rata-rata dari sekumpulan data. Berikut ini adalah perbandingan data aktual, data smoothing SES menggunakan $\alpha=0.1, \alpha=0.9$ dan $\mathrm{S} 0=\mathrm{X} 1, \mathrm{~S} 0=\bar{X}$.

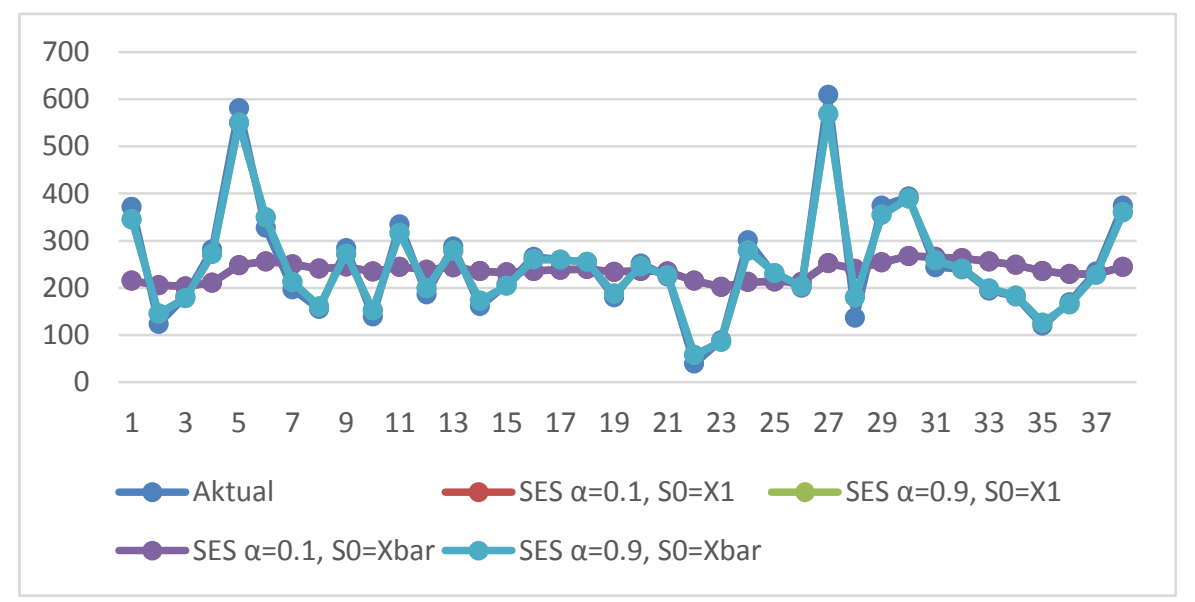

Gambar 3.2. Plot data aktual dan peramalan menggunakan SES dengan $\alpha=0.1$ dan $\alpha=0.9$

Gambar 2 menunjukkan plot data ramalam menggunakan metode SES pada $\alpha=0.9$ memberikan hasil yang lebih mirip dengan data aktual, Sedangkan plot data ramalan menggunakan SES dengan $\alpha=0.1$ menunjukkan hasil cukup menyimpang dari data aktual. Dalam simulasi ini, terlihat bahwa nilai $\alpha$ memberi pengaruh terhadap keakuarasian pada peramalan. Namun tidak demikian dengan nilai $\mathrm{S} 0$. Pada uji coba $\mathrm{S} 0=\mathrm{X} 1$ memberikan hasil yang sama saat uji coba pada $\mathrm{S} 0=\bar{X}$.

\subsection{Model Naive}

Berikutnya dilakukan peramalan menggunakan model naïve dan hasil peramalan yang diperoleh ditunjukkan pada Gambar 3 berikut ini. 


\section{Arnita, Dina Novriyana, Faridawaty Marpaung, Anisa}

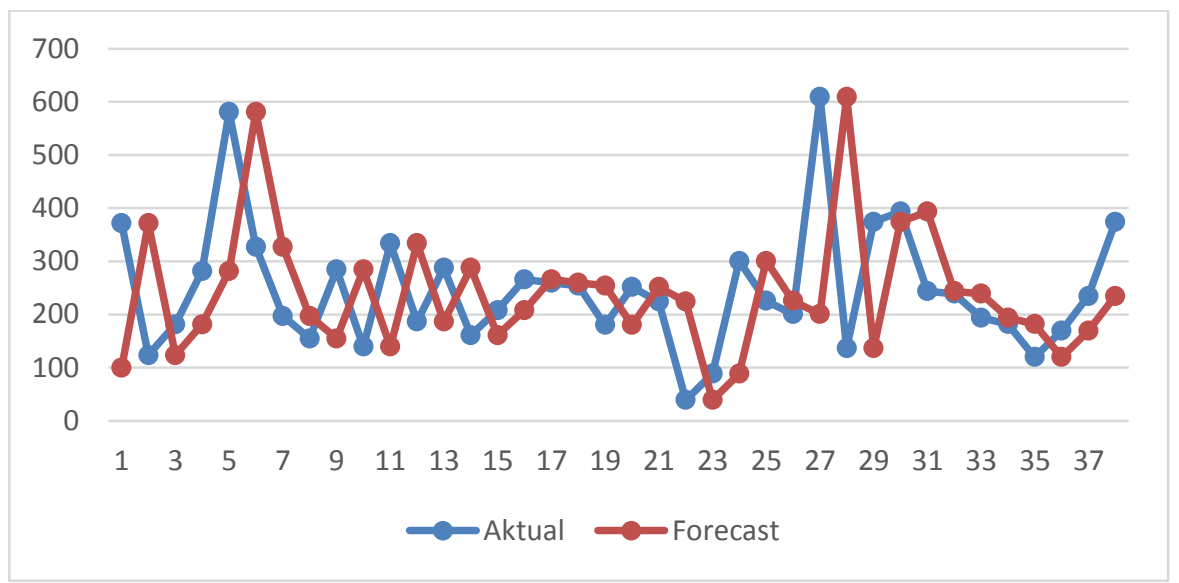

Gambar 3.3. Plot perbandingan data aktual dan model Naive

Gambar 3.3 menunjukkan bahwa model Naïve belum begitu baik melakukan fitting terhadap data aktual. Hal ini terlihat dari plot model Naïve yang masih menyimpang dari plot data aktual.

\subsection{Metode SARIMA}

Tahap identifikasi model dilakukan untuk mendapatkan model SARIMA yang sesuai. Tahap ini dilakukan dengan melihat pola data menggunakan plot Autocorrelation Function (ACF ) yang mengindikasikan model Auto Regressive (AR) dan Partial Autocorrelatin Function (PACF) yang mengindikasikan model Moving Average (MA). Berikut ini adalah plot ACF dan PACF dari data curah hujan tahun 2009-2019.

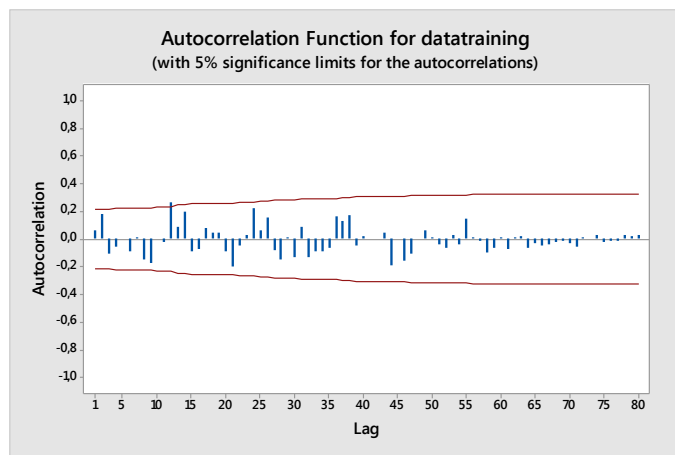

Gambar 3.4. Plot ACF Curah Hujan

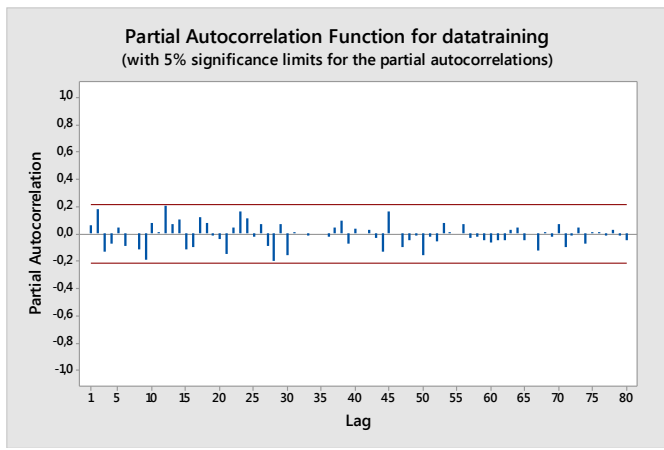

Gambar 3.5. Plot PACF Curah Hujan

Dari Gambar 3.4 dan Gambar 3.5, Plot ACF dan PACF langsung mendekati nilai 0 pada lag awal dengan kata lain plot ACF dan PACF cut off pada lag 1. Dari plot ACF dan PACF juga teridentifikasi pola musiman pada lag 12. Pada pola musiman plot ACF cut off pada lag 4 dan plot PACF cut off pada lag 3 . Sehingga kandidat model yang dipilih adalah SARIMA $(1,0,1)(4,0,3)^{12}$. Berikut ini adalah hasil estimasi model SARIMA $(1,0,1)(4,0,3)^{12}$

Tabel 3.2. Hasil Estimasi Model SARIMA $(1,0,1)(4,0,3)^{12}$ 


\section{Arnita, Dina Novriyana, Faridawaty Marpaung, Anisa}

\begin{tabular}{cccccc}
\hline Type & Coef & SE & Coef & T & P \\
\hline AR & 1 & 0,5047 & 0,7773 & 0,65 & 0,518 \\
SAR & 12 & $-0,0094$ & 0,2473 & $-0,04$ & 0,97 \\
SAR & 24 & 0,574 & 0,1257 & 4,57 & 0 \\
SAR & 36 & 0,7624 & 0,0945 & 8,07 & 0 \\
SAR & 48 & $-0,412$ & 0,2225 & $-1,85$ & 0,068 \\
MA & 1 & 0,4004 & 0,8254 & 0,49 & 0,629 \\
SMA & 12 & $-0,3483$ & 0,2806 & $-1,24$ & 0,218 \\
SMA & 24 & 0,2619 & 0,2496 & 1,05 & 0,297 \\
SMA & 36 & 0,7297 & 0,1808 & 4,03 & 0 \\
Constant & 8,725 & 3,274 & 2,66 & 0,009 & \\
Mean & 207,15 & 77,75 & & & \\
\hline
\end{tabular}

Pada Tabel 3.2 diperoleh nilai koefisien AR, MA, SAR, dan SMA $<1$, artinya asumsi kestasioneran telah terpenuhi.

Tabel 3.3. Uji Ljung-Box Model SARIMA $(1,0,1)(4,0,3)^{12}$

\begin{tabular}{lrr}
\hline \multicolumn{3}{c}{ Modified Box-Pierce (Ljung-Box) Chi-Square statistic } \\
\hline Lag & 12 & 24 \\
Chi-Square & 6,5 & 19,6 \\
DF & 2 & 14 \\
P-Value & 0,04 & 0,143 \\
\hline
\end{tabular}

Dari hasil estimasi yang ditunjukkan pada Tabel 3.3, dapat dilihat bahwa uji Ljung Box pada model SARIMA $(1,0,1)(4,0,3)^{12}$ memiliki nilai P-value $>0,05$ pada lag 24 . Artinya model ini telah memenuhi asumsi white noise yaitu residual sudah bersifat acak. Model ini merupakan model yang paling sederhana, karena jika nilai AR dan MA dinaikkan model tidak dapat diestimasi.

\subsection{Evaluasi Model}

Pada tahap ini akan dibandingkan hasil peramalan dari metode SES dengan $\alpha=0.1$, $\alpha=0.9$ dan S0 $=\mathrm{X} 1, \mathrm{~S} 0=\bar{X}$, Naïve Model, dan SARIMA. Adapun hasil peramalan dari masing-masing model diperlihatkan pada gambar berikut. 


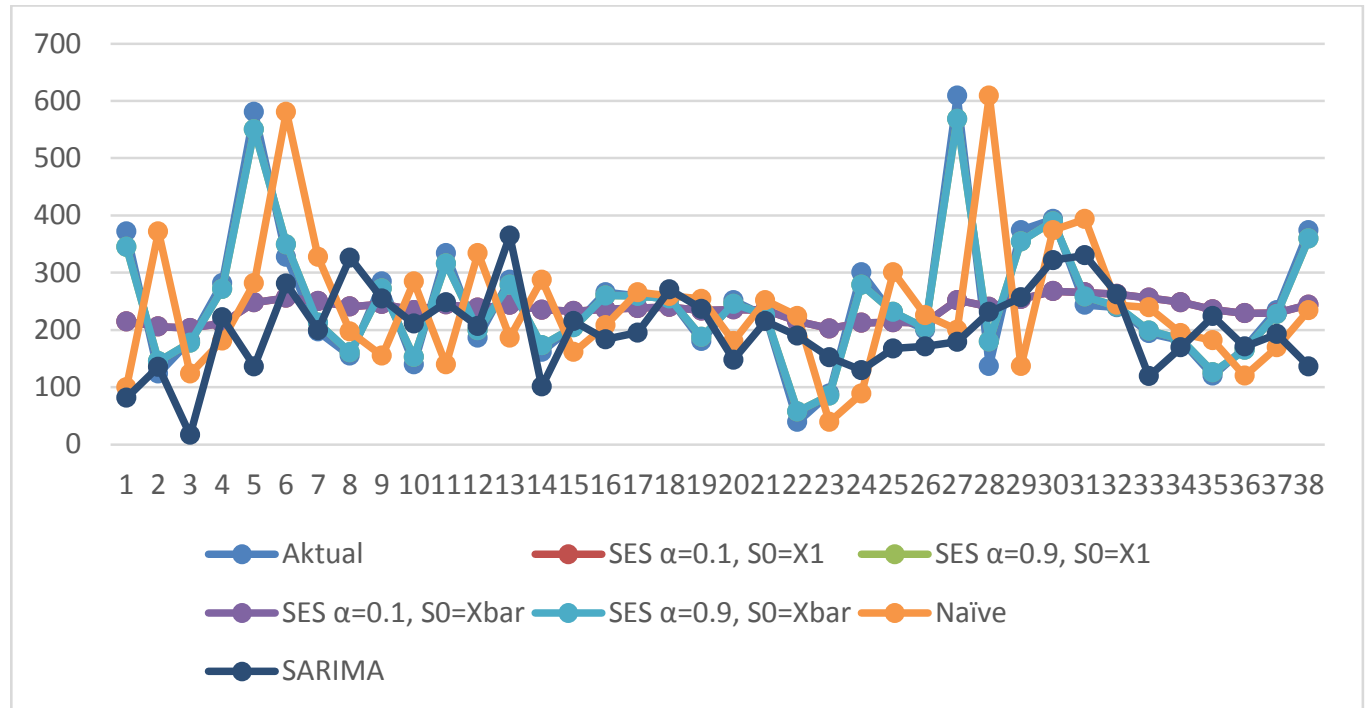

Gambar 3.6. Perbandingan Plot Peramalan Curah Hujan Menggunakan Metode SES, Naive Model, dan SARIMA

Dari Gambar 3.6 dapat dilihat bahwa model SES dengan $\alpha=0.9$ lebih mendekati data aktual. Sedangkan model Naïve menunjukkan pola yang hampir sama, namun posisi titik pada data menyimpang dari posisi data aktual. Dan model SARIMA menunjukkan bahwa data ramalan mendekati rata-rata dari data aktual. Untuk membandingkan keakuratan masing-masing model, dilakukan evaluasi model dengan menghitung nilai error seperti yang terdapat pada Tabel 3.4 berikut ini.

Tabel 3.4. Perbandingan Keakuratan Masing-Masing Model

\begin{tabular}{lccccrrr}
\hline \multirow{2}{*}{ Evaluasi } & \multicolumn{2}{c}{ SES $\alpha=0,1$} & \multicolumn{2}{c}{ SES $\alpha=0,9$} & \multirow{2}{*}{ Naïve } & \multirow{2}{*}{ SARIMA } \\
\cline { 2 - 5 } & S0 $0=\mathrm{X} 1$ & $\mathrm{~S} 0=\bar{X}$ & $\mathrm{~S} 0=\mathrm{X} 1$ & \multicolumn{1}{c}{$\mathrm{S} 0=\bar{X}$} & \multicolumn{1}{c}{ Model } & \\
\hline MSE & 12123,9292 & 12123,9960 & $\mathbf{2 5 1 , 2 9 6 7}$ & $\mathbf{2 5 1 , 2 9 6 7}$ & 27669,159 & 19707,42 \\
RMSE & 79,7944 & 79,7945 & $\mathbf{1 1 , 9 5 3 8}$ & $\mathbf{1 1 , 9 5 3 8}$ & 125,003 & 95,92511 \\
MAE & 11,0481 & 11,0492 & $\mathbf{0 , 7 3 8 6}$ & $\mathbf{0 , 7 3 8 6}$ & 7,229 & 45,47327 \\
MAPE & $21,03 \%$ & $21,03 \%$ & $\mathbf{2 , 4 7 \%}$ & $\mathbf{2 , 4 7 \%}$ & $24,8 \%$ & $2,93 \%$ \\
\hline
\end{tabular}

Tabel 3.4 di atas dapat dijelaskan bahwa model SES dengan $\alpha=0.9$ lebih akurat dalam melakukan peramalan. Hal ini ditunjukkan bahwa metode SES dengan $\alpha=0.9$ mampu memberikan nilai error yang paling kecil dibanding model lainnya. Dan nilai error (MAPE) yang dihasilkan masuk dalam kategori high accurate forecast [1]. Sedangkan metode SARIMA memberikan nilai error terkecil kedua setelah metode SES $\alpha=0.9$. Artinya peramalan curah hujan di kota Medan yang dilakukan model SARIMA juga mampu memberikan nilai akurasi yang sangat tinggi dengan nilai MAPE $=2,93 \%$ [15]

\section{Kesimpulan}




\section{Arnita, Dina Novriyana, Faridawaty Marpaung, Anisa}

Berdasarkan simulasi yang sudah dilakukan, diperoleh kesimpulan bahwa metode SES dengan $\alpha=0.9$, dan Model SARIMA $(1,0,1)(4,0,3)^{12}$ mampu memberikan nilai akurasi yang tinggi dalam meramalkan curah hujan di Kota Medan. Hal ini ditunjukkan dengan

nilai MAPE pada metode SES dengan $\alpha=0.9$ dan Model SARIMA $(1,0,1)(4,0,3)^{12}$ masing-masing adalah $2,47 \%$ dan $2,93 \%$.

\section{Daftar Pustaka}

[1] Mantgomery, D.C., Jennings, C.L., Kulachi, M., 2015. Introduction to Time Series Analysis and Forecasting, 2nd Ed. John Wiley \& Sons, New Jersey.

[2] Soelaeman, I., 2011. Analisis Runtun Waktu. Universitas Terbuka, Tangerang.

[3] Hartono, A., Dwijana, D., Handiwidjojo, W. Perbandingan Metode Single Exponential Smoothingdan Metode Exponential Smoothing Adjusted Fortrend (Holt's Method) Untuk Meramalkan Penjualan.Studi Kasus: Toko Onderdil Mobil "Prodi, Purwodadi". Jurnal EKSIS Vol 05 No 01 Mei 2012: halaman8-18.

[4] Montgomery, D. C, Johnson L.A, Gardiner, JS. 1990. Forecasting and Time Series Analysis,McGraw-Hill, Inc, ISBN 0-07-042858-1.

[5] Sadew, E, 2013. Perbandingan Beberapa Metode Time Series pada Peramalan Jumlah Kunjungan Wisatawan Mancanegara: Studi Kasus di Kabupaten Karimun, Provinsi Kepulauan Riau. Researchgate DOI: 10.13140/RG.2.2.26922.62403/ Badan Pusat Statistik, DOI:10.13140/RG.2.2.26922.62403.

[6] Aldrian, E., Susanto, R.D. 2003. Identification of Three Dominant Rainfall Regions within Indonesia and Their Relationship to Sea Surface Temperature. International Journal of Climatology, 23(12), 1435-1452. doi: 10.1002/joc.950 .

[7] Prasetyo, B., Irwandi, H., Pusparini, N., 2018. Karakteristik Curah Hujan Berdasarkan Ragam Topografi Di Sumatera Utara. Jurnal Sains \& Teknologi Modifikasi Cuaca, Vol.19 No.1, 2018: $11-20$.

[8] Andrian, Y., Ningsih., E., 2014. Prediksi Curah Hujan Di Kota Medan Menggunakan Metode Backpropagation Neural Network. Prosiding Seminar Nasional Informatika, Medan.

[9] Makridakis, S. S. C. Wheelwright, and V.E. McGee., 1999. Metode dan Aplikasi Peramalan. Erlangga, Jakarta.

[10] Hanke, J.E., Wichern, D.W., 2005. Bussiness Forecasting, 8th Ed. Pearson Prentice Hall, New Jersey.

[11] Render, B., Heizer J., 2006. Manajemen Operasi 7th Edition. Salemba Empat, Jakarta. 
[12] Fachrurrazi Sayed, 2015. Peramalan Penjualan Obat Menggunakan Metode Single Exponential Smoothing pada Toko Obat Bintang Geurugok. Jurnal Tehcsi, Vol. 6 No. 1, April 2015.

[13] Soelaeman, I., 2011. Analisis Runtun Waktu. Universitas Terbuka, Tangerang.

[14] Airuzsh, Deltha., 2017. Peramalan Indeks Harga Konsumen dengan Metode SSA dan SARIMA. Jurnal Matematika “Mantik”, 3(2), 74-82.

[15] Ukhra, A.U., 2014. Pemodelan dan Peramalan Data Deret Waktu dengan Metode Seasonal ARIMA. Jurnal Matematika, 3(3), 59-67. 